\title{
THE LIBRARY OF JOHN WEBSTER
}

\section{INTRODUCTION}

The manuscript of the catalogue of the library of Dr John Webster of Clitheroe is to be found today in the archives of Chetham's library, Manchester (Chetham MS A.6.47). It was previously in the ownership of the celebrated Lancashire antiquarian, James Crossley, who was himself given the manuscript on 12 June 1876 by a friend, the Reverend Thomas Corser of Stand. ${ }^{46}$ The manuscript consists of twenty-two foliated leaves bound with marbled boards and leather spine, and is almost certainly a copy of an original draft, composed by Webster himself, probably for the purpose of evaluating his estate. ${ }^{47}$ In Webster's will, dated 3 January 1680 (see Appendix 1), the contents of the library were valued at $£ 400$, a figure roughly approximating to the more accurate catalogue evaluation of $£ 4026 \mathrm{~s}$. $10 \mathrm{~d}$.

The catalogue is systematically arranged according to subject and book-size and would appear to reflect the original plan of the books as they actually appeared on the shelves of Webster's library. It comprises fifteen sections (which, for the sake of convenience, I have labelled A to $\mathrm{O}$ ) with 1501 entries in total. This figure, however, is not an accurate assessment of the number of volumes once possessed by Webster. Although it is impossible to give a precise figure, ${ }^{48}$ a conservative estimate would indicate a total number of volumes in the region of 1662 (a figure which includes works from Section $\mathbf{M}$ which were not in Webster's possession at the time the catalogue was produced).

Clearly, the sheer size of Webster's library is one of its most striking features, but what else, apart from the broadest generalizations, can it tell us about the owner of this collection? The limited use of such evidence is all too obvious. For example, even if it were possible to read every work, how would this help us to understand how a seventeenth-century reader such as Webster would interpret the same information and knowledge? How can we know whether or not Webster even read some or all of these works? Many of the volumes, particularly the older ones, were almost certainly the fruits of inheritance. Others may constitute unread gifts or volumes acquired merely for the sake of collection. To make matters worse, the library itself has not survived

\footnotetext{
46 Corser had originally intended to publish the catalogue, along with a "fuller life" of Webster, in the Proceedings of the Chetham Society; see Pots's discovery of witches ... reprinted from the original edition of 1613, Publications of the Chetham Society, new series, no. 6, Manchester, 1845, Appendix ('Works suggested for publication').

${ }^{47}$ For evidence of Webster's authorship, see below, item 1176: "2 my owne Sermon bookes". This is presumably a reference to Webster's The judgement set [also item 451].

${ }^{48}$ Difficulties encountered in this respect are largely due to the vague descriptions that the cataloguer frequently employed in the composition of the manuscript. Item 1197, for example, is simply described as "H:N: Workes". Likewise, the use of "Opera" to describe an unknown quantity of books (e.g., item 1390: "Opera Jo: Wigandi") makes it impossible to arrive at an accurate figure for the total number of volumes in the collection. For the sake of statistical analysis, I have counted such items as comprising one volume only.
} 
intact, nor, as far as I am aware, have individual volumes come to light, which might have provided some clues to Webster's reading habits. In the absence of annotated books in Webster's handwriting, one is bound to accept that the catalogue as it stands represents for the historian only a limited record of one man's intellectual and literary tastes. ${ }^{49}$

Notwithstanding the very real methodological problems and consequent limitations that beset a study such as this, it is possible to elicit much useful information which might add to our overall picture of Webster. To a very large extent, I am encouraged in my optimism by the invaluable evidence of the breadth of Webster's reading to be found in his published writings. In all but his earliest theological writings, Webster included comprehensive and often detailed citations of references which $I$ have included in the main body of the catalogue. ${ }^{50}$ An analysis of these suggests that in the writing of just three works (Academiarum examen, Metallographia, and The displaying of supposed witchcraft), Webster cited over two hundred authorities, or roughly fourteen per cent of the total number of items in his possession in 1682. Such a high figure (given the low sample) certainly suggests that Webster was no mere dilettante collector of books, a view confirmed by Webster himself in 1677, when he confessed to having led "a solitary and sedentary life ... having had more converse with the dead than the living, that is, more with Books than with Men". 51

All other arguments to one side, the sheer size and value of Webster's library is surely testament enough to his voracious appetite for the printed word. Such a collection could only have been amassed at considerable personal expense, and Webster was, after all, a man of only moderate income and wealth. Moreover, geographical isolation, particularly from the specialist book markets in the new medical and scientific literature that features so prominently in Webster's library, must have placed real constraints on Webster's ability to purchase books. Some instances of individual items will serve to illustrate the point. The most expensive item in the library, Robert Fludd's five-volume Opera (Oppenheim \& Frankfurt, 1617-26: item 1), was valued in 1680 at the staggering figure of $£ 910 s$. $0 d$. A colour edition of Gerard Mercator's Atlas (Amsterdam, 1636-38; 1641: item 77) was priced at $£ 8$, and a three-volume edition of Conrad Gesner's Historia animalium (Zurich, 1551-58: item 83) at £6 10s. $0 d$.

In the case of less expensive items, the greatest problem for Webster was probably inaccessibility to booksellers. This fact alone probably accounts for one of the more curious features of Webster's library, namely the virtual absence of books dating from the period after 1658-59. Although the problem of identification of editions makes it

\footnotetext{
49 I hope it will be possible to locate works that once formed part of Webster's library. According to James Crossley in 1845, he had in his possession "two books which appear to have at one time formed part of his collection, from having his favourite signature, Johannes Hyphantes, in his autograph, on the title pages"; introduction to Potts's discovery, op. cit., note 46 above, p. 16n. The librarian of Chetham's Library, Manchester, kindly informs me that at Crossley's death he owned approximately 60,000 to 90,000 volumes which were dispersed by auction in two portions. Since the catalogues of both sales survive, it should one day prove possible to locate some of the volumes that were once in Webster's possession.

${ }^{50}$ In some cases, this has allowed me to identify precise editions. For the great majority of items, however, this has proved impossible.

${ }^{51}$ Webster, op. cit., note 15 above, sig.Alv.
} 
impossible to speak with certainty on this issue, the fact that only a handful of items can be positively dated to the period after 1659 does seem to indicate an end to Webster's book buying shortly before the restoration. ${ }^{52}$ The temptation to correlate this disjuncture with Webster's public recantation from the radical cause at roughly the same time (above pp. 6-7) is overwhelming. In all probability, when Webster withdrew from the radical scene in 1657-58, he also severed all links with London and its printers and booksellers, and so ceased to acquire new works of science and literature. One should not assume from this, however, that Webster's love of novelty and books ceased at the restoration. Both his later works, printed in the 1670s, carry numerous references to works of natural philosophy and other subjects which were published after 1659 and which cannot be found in his own library. ${ }^{53}$ During this period then, Webster clearly borrowed books rather than buying them, a change of practice which does not appear to have blunted his desire to remain well-informed.

One source of new information was Martin Lister. In the abbreviated correspondence between the two men which survives, it is clear that Webster's residence in remote Clitheroe was not the barrier that it might at first seem to a man with Webster's thirst for knowledge. For example, in a letter dated 9 October 1674, Webster wrote to Lister thanking him for the loan of two books, one of which had only recently appeared at Copenhagen in the same year. The work in question was, in fact, a reply to the famous adversary of the Paracelsians, Hermann Conringius (1606-81) by the Danish scholar Olaus Borrichius (1626-90), and Webster thanked Lister for the prompt procurement of "such a peice as I have much desired to see, for of all the malicious enemyes of the Hermetick learning, I have often wished to have had Conringius undertaken, which he hath done, and performed beyond all expectation". 54

The Webster-Lister correspondence thus helps to reinforce what is already very apparent from Webster's published works, namely an unquenchable appetite on the part of the Clitheroe physician for up-to-date scientific information. This image of Webster the bibliophile, busily accumulating works of science, medicine, and literature in the period prior to the restoration, does not exactly fit with the stereotypical image of the radical reformer. Excessive veneration of books and the knowledge that they contained was not generally a hallmark of Webster's like-minded colleagues. The chemist, John French, for example, in the preface to A new light of alchymie (1650),

\footnotetext{
52 In the period from 1650 to 1660 , I have counted 112 items that were published exclusively during these years. Of these, only five, or 4.5 per cent, appeared in the years $1659-60$ [items: $26 ; 40 ; 50 ; 484 ; 665$ ]. After 1660 , only a further five, or perhaps six, items can be positively dated from this period [items: $164 ; 322 ; 467 ?$; $694 ; 920 ; 962]$.

${ }_{53}$ This is most striking in the case of The displaying, since Webster possessed no personal copy of either of the tracts by Glanvill and Casaubon which had induced his reply. He also cited a number of important texts relating to the European witchcraft debate which were not in his possession, e.g. Johann Wier's De praestigiis daemonum and King James's Daemonologie. In all, I have counted only thirteen volumes in Webster's library concerned specifically with the subject of witchcraft.

$\$ 4$ Bodleian Library, Oxford, Lister MS. 34, f.173. The work to which Webster referred is Borrichius, Hermetis, Egyptiorum, et chemicorum sapientia ab Hermanni Conringii animadversionibus vindicata, Copenhagen, Petrus Hauboldus, 1674. Webster possessed two works by Conringius, including his full-scale assault upon the ancient origins and veracity of hermetic wisdom, De hermetica Agyptiorum vetere et Paracelsiorum nova medicina liber unus, Helmstadt, Henningus Mullerus, 1648; 2nd ed., 1659 [item 343].
} 
apologized for the publication of this translation because "there are too many books already, and the multitude of them is the greatest cause of our ignorance". In religion, similar claims were made by the spokesmen of the radical sects, yet Webster, who shared the view that book learning and other aids were irrelevant to the acquisition of grace, was simultaneously establishing a vast library that included a large percentage of orthodox theological writings. 55

In Webster's case at least, the charge of "ignorance" which was levelled against him in the $1650 \mathrm{~s}$, and has been repeated since, was clearly unfounded. ${ }^{56}$ Webster, in fact, never condemned book learning per se, even in his most vitriolic attacks upon the scholastic teachers of Oxford and Cambridge. The thrust of his argument was against what he perceived as the total reliance of the schools upon "poring continually upon a few paper Idols and unexperienced Authors: as though we could fathome the Universe by our shallow imaginations, or ... weak brains". It was for this reason that Webster advised the adoption of Baconian inductivism in natural philosophy and other branches of learning in order to redress the balance of university studies. Henceforth students should proceed to learn about the secrets of nature through the use of "manual operation, and ocular experiment", an eventuality which would "never come to pass, unless they have laboratories as well as Libraries, and work in the fire, [rather] than build Castles in the Air." 57

Of Webster's breadth of learning and love of books there can be little serious doubt. But what of the actual contents of his library? Classification of each entry by subject (Table 1) and language (Table 2) is an obvious starting-point, notwithstanding certain important reservations as to the reliability of the statistical evidence used to determine these categories. In the case of Table 1 , the most serious caveat concerns the quite often insuperable problem of definitional status. Certain works obviously fall under more than one broad subject classification (e.g. items 102; 895; Pierre de la Primaudaye's encyclopaedic French academy), and these have been entered under the rather unhelpful category of 'Miscellaneous works'. Under this heading I have also included the various collected works of authors such as Aristotle [79], Plato [43;1180], Bacon [694], and Nicholas of Cusa [33], as well as a whole series of volumes on such diverse topics as hunting [194;888;1192], prophecy [406;684;1485], tobacco-smoking [945], etc. For the purposes of statistical accuracy, I have also excluded from analysis thirty-six volumes which defy classification of any kind (e.g., items $1100 ; 1101 ; 1102 ; 1103 ; 1104)$. Similarly, in Table 2, forty-three volumes have been omitted from the total number of works classified by language (e.g., item 1351: "4 litle books of pdestinacon \& such like").

\footnotetext{
55 Michael Sendivogius, A new light of alchymie ... translated . . by John] F[rench], London, R. Cotes, 1650, sigs. A4r-v; cf. Everard Maynwaring, Medicus absolutus, London, 1668, p. 135; Anon., A rational discours touching the universal medicin, London, 1664, p. 7.

56 Mark Curtis, for example, has described Webster as "an ignorant and fanatical critic of the universities"; Curtis, Oxford and Cambridge in transition, 1558-1642, Oxford, Clarendon Press, 1959, p. 274. Of his contemporary critics, note that Webster possessed a copy of John Wilkins' and Seth Ward's reply to Webster's critique of the universities [item 446].

57 John Webster, op. cit., note 4 above, pp. 68, 106. Webster did, in fact, possess his own laboratory in Clitheroe, which he referred to as "my Furnace house"; see Appendix 1.
} 
TABLE I. THE LIBRARY OF DR JOHN WEBSTER CLASSIFIED ACCORDING TO SUBJECT

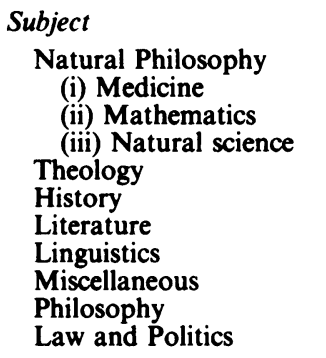

TOTAL

\begin{tabular}{cc} 
Total & Percentage \\
647 & $39 \cdot 8$ \\
{$[242]$} & {$[14 \cdot 9]$} \\
{$[79]$} & {$[4 \cdot 9]$} \\
{$[326]$} & {$[20 \cdot 0]$} \\
397 & $24 \cdot 4$ \\
169 & $10 \cdot 4$ \\
148 & $9 \cdot 1$ \\
90 & $5 \cdot 5$ \\
69 & $4 \cdot 25$ \\
56 & $3 \cdot 45$ \\
50 & $3 \cdot 1$ \\
\hline $1626^{*}$ & 100 \\
\hline
\end{tabular}

*Excluding 36 unidentified volumes

\begin{tabular}{lrc} 
TABLE 2. THE LIBRARY OF DR JOHN WEBSTER CLASSIFIED ACCORDING TO LANGUAGE & Percentage \\
Language & Total & $59 \cdot 7$ \\
Latin & 967 & $25 \cdot 0$ \\
English & 405 & 5.4 \\
French & 87 & $2 \cdot 1$ \\
Italian & 34 & $1 \cdot 6$ \\
Greek-Latin & 26 & $1 \cdot 2$ \\
German & 19 & 0.95 \\
Spanish & 15 & $0 \cdot 95$ \\
Hebrew & 15 & $0 \cdot 75$ \\
Greek & 12 & $0 \cdot 1$ \\
Dutch & 2 & $0 \cdot 05$ \\
Arabic & 1 & $2 \cdot 2$ \\
Miscellaneous (i.e., polyglot dictionaries, grammars, etc.) & 36 & 100 \\
\multicolumn{1}{c}{ TOTAL } & $1619 *$ & \\
\cline { 2 - 2 }
\end{tabular}

*Excluding 43 unidentified volumes

\section{NATURAL PHILOSOPHY}

By far the largest category of books owned by Webster was that which I have classified under the general heading of natural philosophy (647 volumes or approximately forty per cent of the total number of volumes in the library). Over half (326) were concerned with what I have rather artificially termed natural science. The remaining works have been classified under the equally imprecise headings of medicine (242) and mathematics (79). Within the major sub-division of natural science are to be found volumes on a wide range of subjects including astronomy, botany, chemistry, cosmography, geography, husbandry, mineralogy, optics, psychology, witchcraft, and zoology. Not surprisingly, however, the largest group of works within this sub-division comprises those which for the sake of simplicity (if not complete accuracy) one might best describe as "occult philosophy"-i.e., alchemy, astrology, cabbalism, and natural magic. Excluding works of occult medicine, Webster owned over one hundred volumes of occult science.

Such are the bare statistics, but what of the range and content of this extraordinarily impressive collection of scientific and medical literature? One conclusion is inescapable. On the evidence of both his published writings and his library, Webster was a committed eclectic who did not appear to perceive any contradiction in the diversity of his scientific reading and interests. His critics, on the other hand, accused 
him of inconsistency and ignorance when in the 1650s he advocated the replacement of sterile Aristotelianism in the universities with a new curriculum based upon a wide range of modern scientific and philosophical beliefs. Alongside Robert Fludd and the Paracelsians, Webster praised the revival of Platonism (undertaken by Patrizi and Ficino), Democritean atomism (by Descartes, Regius, Holwarda, and Magnenus), and Epicureanism (by Gassendi), as well as the works of Telesio, Gilbert, and Bacon. This was not, as recently suggested, a mere exercise in name-dropping. In Webster's library are to be found works by all these authors, including a two-volume edition of Descartes' Opera (Amsterdam, 1650) [315] and an eight-volume edition of Bacon's Works (Amsterdam, 1660-63) [694].58 Of one fact we can be absolutely certain. Webster's assault on the universities in the 1650s was not simply the work of an "ignorant fanatic" hell-bent on destroying the educational status quo. It was rather the product of extensive reading in the literature of the new science, in all its various forms, which Webster continued to cultivate throughout the $1650 \mathrm{~s}^{59}$

Another equally important element of Webster's eclecticism was his solid grounding in the learning of the "ancients", and in particular Aristotle, whom he regarded as the root of scientific error. Webster not only possessed a large edition of Aristotle's Works in Greek and Latin [79], but also a whole series of learned commentaries and textbooks on Aristotelian natural philosophy. The commentary of the Jesuit, Franciscus Toletus [241], and the textbooks of Giacomo Zabarella [236] and Joannes Magirus [778; 821] were standard reading at Oxford and Cambridge in the late-sixteenth and earlyseventeenth centuries, as were the commentaries of another Jesuit, Petrus Fonseca [233], and Julius Pacius [234] on Aristotle's Metaphysics and Logic respectively. ${ }^{60}$ It is possible to add to this list a whole host of lesser commentaries and manuals by Jesuit and Protestant scholars. Among the former, Webster owned three volumes of commentaries by the learned Jesuits of the university of Coimbra [237; 238; 239], two copies of Benedictus Pererius' Physica [788; 815], and an unspecified three-volume edition of commentaries by Antonio Ruvio [820]. ${ }^{61}$ Protestant authors are represented

\footnotetext{
58 Ibid.,pp. 105-106. Pride of place in this illustrious collection of scientific and philosophical investigators was reserved for the English hermeticist, Robert Fludd (1574-1637), whose "elaborate writings ... the world never had a more rare, experimental and perfect piece". Ibid., p. 105. Admiration for Fludd was reflected in Webster's ownership of Fludd's works in five large volumes [item 1], the most valuable item in the whole library (above, p. 16).

59 Of the 154 items (178 volumes) published after 1650 in Webster's possession, 73 per cent were concerned with some aspect of natural philosophy. Again, it is impossible to discern a theme or pattern to these works, which were concerned with a whole variety of topics and scientific view-points.

60 Toletus(1532-96) was created cardinal by Pope Clement VIII in 1593, and played an important rôle in the reconversion of Henry IV of France. Zabarella (1533-89) taught at the University of Padua for twenty-six years, his lectures there forming the basis of item 236. Magirus (d. 1596) taught philosophy at the university of Marburg. For the use of the works of these authors in the English universities, see Curtis, op. cit., note 56 above, pp. 110-112; H.F. Kearney, Scholars and gentlemen: universities and society in pre-industrial Britain, $1500-1700$, London, Faber \& Faber, 1970, p. 105. Webster's concern with Aristotelian metaphysics and logic is discussed in more detail below, pp. 40, 41 .

${ }^{61}$ Pererius (1535-1610) had an international reputation in all fields of learning, including rhetoric, philosophy, and theology. Lynn Thorndike has suggested that his Physica was used "as a text in Jesuit schools in teaching the Physics and natural philosophy of Aristotle"; Thorndike, A history of magic and experimental science, New York, Macmillan, 1929-58, 8 vols., vol. 6, pp. 409-413. Ruvio (1548-1615) studied extensively in Mexico for twenty-five years before returning to his native Spain.
} 
by Johann Thomas Freigius [830] and the Scottish philosopher Gilbert Jacchaeus or Jack [1120a]. ${ }^{62}$

One possible explanation for Webster's possession of such a large and varied selection of Aristotelian works of science is that Webster, as Anthony Wood, suggested, spent some time at Cambridge in his youth (above p. 1). Even if this was the case, it is still possible that Webster continued to collect such works for the explicit purpose of composing a radical critique of the Aristotelian system as it was commonly taught in the schools. This, after all, was the chief purpose of Academiarum examen in which he hinted at his own complete familiarity with the writings of Aristotle:

He [Aristotle] denies in the twelth of his Metaphysicks that God takes care of minute, and small things; in his books De Coelo he makes the world eternal and increate; in his Physicks he teacheth that nothing can be made ex nihilo; in his books De anima and of Ethicks, he denies the possibility of the resurrection of the dead, and in many places doth deny the immortality of the soul . . . and yet this is the man that is onely thought worthy to be the father of Christian Philosophy. ${ }^{63}$

The key to Webster's rejection of the Aristotelian system is clear. As a pagan, he was not fit to carry the title of "father of Christian Philosophy", a view consistently repeated by the radical sectaries in the 1650 s. Furthermore, the high proportion of Jesuit scholars in Webster's library, many of them orthodox Aristotelians, must have strengthened Webster's conviction that herein lay the route to anti-Christian ignorance. ${ }^{64}$ To combat the continuing support for Aristotle in Protestant academic circles, Webster therefore turned to the scholars of the pansophist enlightenment for guidance and support. Undoubtedly one of the leading figures in this movement was the Italian neo-Platonist Francesco Patrizi (1529-97), who sought, in his Nova de universis philosophia [36] to construct a reformed Christian natural philosophy on hermetic and neo-Platonic lines. The heir to this tradition in the seventeenth century was the Bohemian Protestant and exile, Jan Amos Komenský or Comenius (1592-1670), who was himself taught by the Calvinist syncretist and encyclopaedist, Johann Heinrich Alsted (1588-1638). Webster possessed eleven volumes of Alsted's works, including a two-volume edition of the celebrated Encyclopaedia [232], as well as four volumes by Comenius, one of which, Pansophiae prodromus [686], was intended as a blueprint for pansophic reform. ${ }^{65}$

\footnotetext{
${ }^{62}$ Freigius(b. 1543)wasacelebrated Aristoteliannaturalphilosopher.Jacchaeus(1578?-1628)wasastudent of Marischal College, Aberdeen, who, after studying at Helmstadt and Herborn, was appointed to the chair of philosophy at Leyden (1604). A friend of Hugo de Groot (Grotius), he was the first to teach metaphysics at the Dutch university. For Jacchaeus, see DNB, vol. 10, pp. 522-523.

63 John Webster, op. cit., note 4 above, p. 53 (my italics). Other works of Aristotelian science in Webster's possession included four lesser volumes by Henningus Arnisaeus [1467], Jacobus Cheyneius [795], Franciscus Titelman [813], and Joannes Velcurio [700].

${ }^{64}$ Of Jesuit natural philosophers, Webster remarked that it was "the custom of those kind of men to seem ignorant of nothing, when indeed experimentally they scarce know anything"; Webster, op. cit., note 21 above, p. 86. He nonetheless owned works by twenty-five Jesuit scholars (thirty-two volumes in all), fifteen of which were concerned specifically with some aspect of natural philosophy [items $29 ; 39 ; 87 ; 223 ; 233 ; 241$; $295 ; 317 ; 395 ; 497 ; 788 ; 815 ; 820 ; 919 ; 959$ ].

65 John Webster, op. cit., note 4 above, p. 105. Of the remaining three works by Comenius, two were concerned with the reform of language teaching $[862 ; 870]$ see below $p$. 39 , and the other was an attempt to reconcile the study of nature with the truths of the Christian religion [655]. Such thinking, which lay at the root of much of Webster's own reform proposals, was shared by Comenius's English patron, Robert Greville (1608-43), whose The nature of truth [1365] was also in Webster's possession. An earlier example of this concern for a truly Christian natural philosophy can be found in the work of the French Huguenot, Lambert
} 
The guiding spirit behind the work of these men was the rediscovery of the original unity between man, nature, and God, an enterprise which, if successful, would lead to an end to religious and intellectual division in Europe. One aspect of the pansophist vision was the revival of Renaissance hermeticism. For Webster and others, here lay the answer to the stale and corrupting paganism that continued to contaminate the learning of the academies in mid-seventeenth-century England. The various branches of hermetic learning are all well-represented in Webster's library, with particular emphasis upon the art of alchemy as taught by Paracelsus (1493-1541) and his followers. According to Webster in Academiarum examen, "the secrets of nature" were more likely to be uncovered by the study of this one subject than "by all the Peripatetick Philosophy in the world". Such faith is clearly reflected in Webster's large holding of Paracelsian literature. In all, he owned fifteen volumes [11 items] of Paracelsus' writings, in English, German, and Latin, including the most recent edition of the Opera omnia published at Geneva in $1658[16] \cdot{ }^{66}$ In addition to this substantial body of original works, Webster owned a vast collection of medical and alchemical literature, much of it the work of Paracelsians (e.g., six volumes by Michael Maier [332; $334 ; 337 ; 385 ; 598 ; 651])$ as well as earlier exponents of "mystical chymistrye" (e.g., Ramón Lull [282; 540; 575; 576], Roger Bacon [382; 383], George Ripley [466; 633], Basil Valentine [542; 544], etc.). ${ }^{67}$

Since Webster was also an active practitioner of alchemy (see Appendix 1 and the reference to his "furnace house"), the presence of a large number of chemistry manuals in his library takes on an added significance (e.g., those of Beguin [545], Brendel [599], Burnet [335], Davisson [552], Gesner [359; 510] and Hartmann [623]). Interest in furnace construction and the apparatus of chemistry is indicated by the possession of two other works of importance: an English translation of Johann Rudolph Glauber's up-to-date Furni novi philosophici (trans. John French, London, 1651) [462] and an earlier manual of alchemy in Italian by the Dominican Donato D'Eremita [23]. ${ }^{68}$ The latter is a particularly interesting work, since it provides large and detailed illustrations of alchemical instruments and furnace construction, followed by a basic introduction, with glossary, to the alchemist's art.

Webster's active involvement in alchemical experimentation-a passion which seemed to occupy much of his later years ${ }^{69}$ - should not be allowed to disguise his

Daneau (1530-95) [1116]. It was also partially effected by Gulielmus Adolphus Scribonius (fl. late-sixteenth century) in his Physica [1122].

${ }^{66}$ John Webster, op. cit., note 4 above, p. 77. This edition is mistakenly referred to in The displaying, p. 60, as having been printed at Geneva in 1648. Virtually all of the many references to Paracelsus in Webster's final two works are taken from this particular edition.

${ }^{67}$ This impressive collection of Paracelsian writings includes the works and popular translations of Croll [527], Du Chesne [327], Fioravanti [308], Hartmann [312; 623], Ruland [531], Severinus [608], and Toxites [592]. Less familiar are the works of the French alchemist Pierre Jean Fabre [nine volumes: 323; 523a-h], Heinrich Khunrath [619], and Michael Potier [610]. In addition to single-author collections, Webster also owned a number of influential alchemical miscellanies including those of Lazarus Zetzner [five volumes: 536], Philipp Ulstadt [709], and Janus Lacinius [360].

68 Johann Rudolph Glauber (1603?-70?), a native of Franconia, was the author of some thirty treatises on alchemical and related subjects. Webster possessed ten volumes by Glauber [462; 559; 626; 1184], but unfortunately only item 462 is mentioned by name in the catalogue.

${ }^{69}$ See, for example, Webster's correspondence with the naturalist, Martin Lister, where frequent references are to be found to Webster's request for minerals and other matters of alchemical concern. Thus in March 


\section{The library of John Webster}

profound interest in other areas of occult science. Astrology, for example, which Webster described in 1654 as an art that was "high, noble, excellent ... and no way offensive to God or true religion," also features prominently in Webster's library. ${ }^{70}$ There are also a number of volumes on natural magic and cabbalism, the latter represented by such seminal studies as Reuchlin's De verbo mirifico [734] and Pistorius' Artis cabalisticae [27]. One might add to this list a curious little tract by the French eirenicist, Guillaume Postel (1510-81), entitled Absconditorum a constitutione mundi clavis [729]. An exposition of apocalyptic cabbalism, it has been described as an attempt by the author to envisage "a return to the earthly paradise of Genesis" where "mankind will be united in a common speech [Hebrew], a common government, and a common religion based on cabala". ${ }^{71}$ The concordancy with Webster's own concerns in the 1650 s is strikingly apparent (cf. above pp. 3-6).

Works on various aspects of occult philosophy occupy almost a third of Webster's collection of natural science books. Apart from the large number of works which fit no specific heading (sixty-eight; e.g. encyclopaedic compilations of natural curiosities such as Olaus Worm's Museum [4]), the next largest category of works in this section comprises the study of astronomy (twenty-eight volumes). Since Webster was an unqualified supporter of the heliocentric system, one would expect to find a preponderance of pro-Copernican works in his library. This, however, is not the case. For every astronomical text advocating the Copernican system, Webster owned an equivalent volume defending the traditional view of the geocentrists. ${ }^{72}$ Neither were the latter simply the long-forgotten remnant of volumes purchased, in all likelihood, before Webster's birth. The De universo [290] of the Italian astronomer, Scipio Chiaramonti (1565-1653), was not published until 1644 and consisted of a comprehensive defence of the ancients from the criticisms of modern astronomers such as Tycho Brahe and Galileo. Nonetheless, the depth of Webster's interest in the new astronomical theories is clearly illustrated by his ownership of several major texts (Copernicus [211], Galileo [291], and Keppler [485]) and numerous defences of these beliefs (e.g., in works by the Catholic Ismael Boulliau or Bullialdus (1605-94) [193; 425] and the Englishman John Wilkins (1614-72) [453]). In addition, a large collection of lesser authorities, many of

1674, Webster informed Lister that he had prepared "a peice written of the Philosophers Universall Dissolvent, that hath laid by me above this five yeares, being unwilling to make it publike, untill I had by assured practise verified the virtues, and effects of the same"; Bodleian Library, Oxford, Lister MS. 34, f. 157. In the same letter, Webster referred to the Helmontian William Simpson, whom he claimed to have known in York "a good many yeares ago".

70 John Webster, op. cit., note 4 above, p. 51 . Webster praised the achievements of five English astronomers, Ashmole, Lilly, Booker, Sanders, and Culpeper. Of these, two are represented on Webster's shelves: Sanders' Physiognomie [35] and Culpeper's English physitian [666], both first published in 1653. Other works in defence of astrology include those of Dariot [463], Gallucci [217], Giuntini [224], Heydon [640], and Ramesey [652].

${ }^{11}$ William J. Bouwsma, 'Postel and the significance of renaissance cabalism', J. Hist. Ideas, 1954, 15: 231. Other works of cabbalism in Webster's possession were Jacques Gaffarel's Unheard of curiosities [454] and Henry More's Conjectura cabbalistica [974].

72 Traditional texts expounding the Ptolemaic system include those by Alfraganus [1489], Apianus [397], Christmannus [400], Metius [487], Sacro Bosco [503; 1488], Valerius [1490], and Witekind [501]. Additionally, strong support for the geocentric system can be found in such diverse works as Blundeville [1199], Hues [704], La Primaudaye [102; 895], Mazzotta [333], Saluste du Bartas, [885], and Tymme [370]. For Webster's defence of heliocentricity, see John Webster, op. cit., note 4 above, pp. 42-50. 


\section{The library of John Webster}

them favourable to astronomical innovation, was available to Webster. ${ }^{73}$

Two further aspects of Webster's library of natural philosophy demand our attention: mathematics and medicine. From Webster's ownership of seventy-nine volumes of mathematical and related writings (e.g., works on mechanics, surveying, architecture), it is possible to gain some idea of the relative importance that he attached to this particular branch of learning. In Academiarum examen, Webster had reprimanded the universities for their neglect of the mathematical sciences, "the superlative excellency of which transcends the most of all other sciences". In particular, Webster lamented the failure of the universities to appreciate the academic and utilitarian value of such studies (a fault shared, of course, by Francis Bacon). Arithmetic and geometry were both worthy of serious attention, Webster claimed, echoing in the process a similar plea made by John Dee in his preface to Billingsley's edition of Euclid's Geometry [200]. ${ }^{74}$

If the evidence of his library is a faithful guide, Webster's own knowledge of, and commitment to, mathematical investigation was substantial. A solid core of ancient texts $^{75}$ was supplemented by more recent works of sixteenth- ${ }^{76}$ and seventeenthcentury ${ }^{77}$ authorities. To these one might add Webster's English contemporaries, Isaac Barrow [484], William Oughtred [410; 506], and John Wallis [1187]. The latter's Arithmetica infinitorum, published at Oxford in 1655, was the most important new work of its kind in the field of mathematics, and contained within it the roots of the differential calculus. Oughtred's Clavis mathematica [506], on the other hand, was probably the more influential work given its widespread popularity as a comprehensive and comprehensible guide to arithmetic and algebra. As Richard Greaves has noted, the fact that two of these three English mathematicians were unattached to the universities when they completed their mathematical researches tends to lend substance to Webster's view that mathematics was largely ignored in the contemporary curriculum. $^{78}$

Webster's possession of 242 volumes concerned solely with medical practice and theory is a sufficient indication of the significance that he attached to this specialized field of learning. Webster was, of course, a medical practitioner of long experience, who, despite the lack of any formal qualification (he gained official licence to practise in 1669), was clearly well-versed in all aspects of his chosen profession. As with Webster's interest in natural science generally, so too in the field of medicine one cannot fail to admire the astonishing breadth of medical learning covered by his library. Once again, one is struck by the familiar emphasis upon works of a modernist

\footnotetext{
${ }^{73}$ Amongst these: Borel [683], Thomas Digges [426], Maestlin [505], and Schickard [1375], as well as an edition of Aristarchus [424]. Other favourable evaluations of the Copernican system can be found in Hill [1125], Holwarda [572], Le Roy [188], and Ridley [428]. Support for the Tychonic system is to be found in Carpenter [415] and Hopton [480]

${ }^{4} \mathrm{~J}$ John Webster, op. cit., note 4 above, pp. 40-41.

75 Apollonius Pergaeus[212;218], Archimedes[210;213;427], Euclid[200;220a-b;484;488;491], Pappus of Alexandria $[201 ; 424]$

${ }^{76}$ Buteo[500], Leonard Digges[215], Finé[433;435], Lansbergen[420], Mueller Regiomontanus[196], Vieta [195; 218].

${ }_{77}$ Herigone [478], Huygens [391], Napier [696], Snellius [423], Stevin [438].

78 Richard L. Greaves, The puritan revolution and educational thought, New Brunswick, NJ, Rutgers University Press, 1969, p. 72.
} 
hue, but not without due consideration to older authorities. The former trend is most noticeable in the case of works relating to recent anatomical research. Webster's defence of the Harveian circulation, for example, was almost certainly based upon first-hand acquaintance with De motu cordis [731] ${ }^{79}$ Further support for the Harveian system was available to Webster in the writings of numerous distinguished continental anatomists, including Thomas Bartholin [322], Antonius Deusingius [679], and Joannes Veslingius [274]. Interest in other areas of anatomical research and innovation is suggested by a series of works relating to a number of contemporary disputes and discoveries in the field of anatomy. Webster thus possessed five volumes concerned with Jean Pecquet's recent elucidation of the operation of the thoracic duct and lacteal chyle $[298 ; 524 ; 664 ; 730 ; 1188]$, and a further two volumes relating to the controversy between Bartholin and Rudbeck over the discovery of the lymphatic system [617; $668] .{ }^{80}$ In addition, Webster owned the pioneering works of the English anatomists, Francis Glisson [541] and Thomas Wharton [543], on the liver and glands respectively. ${ }^{81}$

This fascination with novelty and medical innovation is evident throughout the catalogue. It should be stressed, however, that Webster, despite his public dismissal of Galenism, was neither ignorant of, nor unconversant with, the more traditional forms of medical theory and practice. Like Aristotle, Galen was not held entirely to blame by Webster for the excessive trust which the physicians and natural philosophers of his own day placed in his writings. ${ }^{82}$ This no doubt helps to explain in part Webster's ownership of numerous conventional Galenic texts (including a five-volume edition of Galen's Opera [566] and a large folio edition of the Methodus medendi [37]). Less easy to account for are the large number of tracts by sixteenth- and seventeenth-century physicians of the traditional Galeno-Hippocratic school of medicine which Webster deigned to despise. Leading representatives of this tradition were Leonhard Fuchs [568; 739], Jean Fernel [21], Joannes Heurnius [7; 355], Petrus Forestus [6; 660], and Daniel Sennert $[9 ; 297 ; 319]$, the latter including an extremely expensive three-volume edition of the Opera omnia [9].

In addition to these treatises of orthodox medical practice and theory, Webster owned twenty-eight volumes concerned solely with the art of surgery, an area of medicine which he almost certainly performed in the course of his own practice in Clitheroe. The most striking feature here is the high incidence of valuable folio editions, which include the works of such renowned authors as Joannes Scultetus [12], Thomas Cornacchinius [13], Wilhelm Fabricius [14], Peter Uffenbach [18], Francescus Peccettius [19], Ambroise Pare [85], and the Englishman, John Woodall [163]. Smaller

\footnotetext{
79 John Webster, op. cit., note 4 above, p. 72; Webster, op. cit., note 15 above, pp. 3-4.

${ }^{80}$ For the controversy between Bartholin and Rudbeck over the discovery of the lymphatic system, see W. Kock, 'Anatomical science and education in the seventeenth century', Analecta Medico-Historica, 1968, 3: 281-292. In addition to Bartholin's Anatomia [322], Webster also owned two volumes of the Danish physician's Historiarum anatomicarum rariorum [621a-b], which were widely cited in The displaying.

${ }_{81}$ Glisson's Anatomia hepatis [541] also included an elaborate defence of Harveian circulation, as well as further insights into the contemporary controversy surrounding the lymphatic system. See Charles Webster, op. cit., note 4 above, pp. $317-318$.

${ }^{82}$ See, forexample, Webster'sdescription of Galenas “industriousand sharpwitted”; Webster, op.cit., note 15 above, p. 20.
} 


\section{The library of John Webster}

in size, but equally popular, were the manuals of the medieval surgeon, Guido de Cauliaco (Guy de Chauliac) [534], the two Englishmen, Thomas Vicary [367] and Thomas Brugis [741], and the works of "that learned and experienced Chirurgion" Felix Wuertz [in German and English: 539 and 1194 respectively]. ${ }^{83}$

Not surprisingly, however, the largest category of works in Webster's medical library falls under the heading of occult and iatrochemical medicine (sixty-eight volumes or $28 \cdot 1$ per cent). The vast majority of these are by authors of the Paracelsian school of medicine. In Webster's eyes, the key to medical reform lay in the study and application of Paracelsian medical methods, which would, he believed, ultimately overthrow the rotten edifice of the Galenic system. Webster was no half-hearted reformer who wished, like some, to amalgamate elements of Galenism (usually its theoretical base) with elements of Paracelsianism (chemical remedies). ${ }^{84}$ On the contrary, he argued tirelessly for the adoption of a new theory of medicine based wholly upon the iatrochemical precepts of Paracelsus and van Helmont. Besides the medical works of Paracelsus (see above p.22), Webster owned a vast array of Paracelsian literature, much of it concerned exclusively with medicine and medical reform. Alongside familiar names such as Oswald Crollius [527], Joseph Du Chesne [327], and Petrus Severinus [608], there appear less well-known works by a variety of continental Paracelsians: Johann Ernst Burggrav [346; 561; 580], Bartholomaeus Carrichter [574], Joannes Finckius [697], Johann Pharamund Rhumel [676; 677], Angelo Sala [287; 1198], and Henningus Scheunemann [614]. To this list, which is by no means exhaustive, one must add the work of the Helmontians. Chief amongst these was the oft-quoted Opera of van Helmont himself [330], as well as a number of tracts by English and continental Helmontians: George Starkey [647a-b], James Thompson [663], Walter Charleton [307], and Franciscus Oswald Grembs [304]. ${ }^{85}$

It would be a mistake, however, to view these works in isolation from those other works of occult philosophy which he owned (above pp. 22-23) and which together constitute 170 volumes or almost ten per cent of the complete contents of the library. Throughout his own published works, he continued to cite favourably authors of the occult and hermetic school of natural philosophy, in full awareness of the damaging criticisms that were consistently levelled against this form of scientific enquiry. ${ }^{86}$ And yet this view of Webster as occult philosopher and hostile critic of traditional science is, I believe, only partially reflected in his library. In medicine, astronomy, mathematics, and various other branches of natural science, Webster was fully conversant with, and

\footnotetext{
83 Webster, op. cit., note 21 above,p. 269. Webster's surgical skills were no doubt put to good use during his period of service in the armies of Parliament in 1648. When he died in 1682, he left surgical instruments to the value of $£ 20$. See Appendix 1 .

84 An example of such a compromise was item 15: Joannes Guinterius, De medicina veteri et nova, Basle, A. Henricpetri, 1571.

${ }^{85}$ Grembs, physician to the archbishop of Salzburg, is an obscure figure of whom very little is known. His Arbor integra et ruinosa hominis [304] consists of 512 pages outlining the various tenets of Helmontian medical theory, which are everywhere favourably compared with those of Galen.

${ }^{86}$ Opposition to Paracelsus is referred to, for example, in Webster, op. cit., note 15 above, pp. 60-62. Webster owned a number of works written by opponents of occult and hermetic medicine and philosophy including Meric Casaubon's exposé of John Dee [40], Conringius' diatribe against the whole edifice of the hermetic and Paracelsian system [343], anti-Paracelsian works by John Cotta [372] and Thomas Erastus [589], and an assault upon the Rosicrucians by Henricus Neuhusius [579],
} 
appreciative of, the contribution which the "ancients" had made in all these fields of learning. Webster's library thus reveals a man of truly eclectic tastes in science who, despite his obscure background and apparent lack of academic credentials, was probably as well-qualified as anyone in England to criticize the deficiencies of contemporary scientific education. ${ }^{87}$

\section{THEOLOGY}

After natural science, the largest category of books in Webster's possession was devoted to theology (397 volumes or 24.4 per cent). In the light of Webster's career as non-conformist and radical critic of the national church (above pp. 1-6), one cannot fail to be impressed and somewhat surprised by the number and range of works contained in this part of the library. For the best part of twenty years, Webster's theological outlook was based upon a fundamental rejection of the premise that other men, through their writings, might act as authoritative guides in religious matters. And yet, from the evidence of his library, it is apparent that Webster was a man steeped in the accumulated wisdom of theologians, ancient and modern, particularly those of the Calvinist school. Works by learned Calvinist professors and preachers on a variety of topics dominate the collection (135 volumes or 34 per cent) and far exceed the relatively small number of works representative of what one might term the "mystical-radical" tradition (only thirty-three volumes or 8.3 per cent) ${ }^{88}$ Indeed, works by Catholic theologians and apologists are almost as numerous as works in the latter category (thirty-one volumes or 7.8 per cent), so that one can only assume that works of this kind possessed a significance for Webster out of all proportion to their size and number. What conclusions, then, can one draw from Webster's library of theological works?

First, it would seem wholly reasonable to suppose, howsoever Webster acquired or read these works, that one of the major early theological influences upon his religious beliefs was orthodox Calvinism. In addition to five volumes of Calvin's writings [91; $156 ; 1253 ; 1269 ; 1301$ ], Webster owned a whole series of doctrinal treatises, polemics, commentaries, and sermons from the pens of many of the leading Calvinists of sixteenth- and seventeenth-century Europe. Particularly prominent are works by the

\footnotetext{
${ }^{87}$ For Webster's eclecticism in practice, see above p. 10.

88 Precise figures for this section of the library are not possible, given some of the rather vague descriptions (e.g., item 1376: "15 litle treatasies in English"). With this in mind, the theological bias of the works in this section may be categorised as follows:

Orthodox Calvinist

Bibles, concordances, etc. $\quad 34$

"Radical-mystical"

Catholic $\quad 31$

Lutheran and other Protestant denominations $\quad 25$

Anglican (non-Calvinist) $\quad 18$

$\begin{array}{ll}\text { Patristic } & 13\end{array}$

Medieval/scholastic $\quad 13$

$\begin{array}{lr}\text { Miscellaneous } & 95\end{array}$

Total number of volumes
} 
French Calvinists, Theodore de Bèze (Beza) (eight volumes), Lambert Daneau (six volumes), Jean Mestrezat (four volumes), and François Du Jon (Junius) (three volumes), with a noticeable emphasis upon a whole range of Huguenot writers (thirty-two volumes in total). ${ }^{89}$ Equally prominent are works representative of the German Calvinist tradition (twenty-eight volumes). Not surprisingly, however, the works of English and Scottish Calvinists, particularly those of puritan persuasion, constitute the majority of volumes in this section (seventy), with substantial contributions from William Ames (five volumes) and Ames's teacher, William Perkins (three volumes); the Elizabethan puritans, Dudley Fenner and Thomas Cartwright (three volumes each); and the Calvinist bishop of Derry, George Downame (three volumes).

Taken as a whole, it is possible to detect recurrent themes in many of these works which may or may not suggest a preoccupation on Webster's part with certain elements of Calvinist thought. For example, there are traces of interest here in the controversy that raged amongst Protestants in Europe, but especially in England, over the threat of Arminianism. Calvinist orthodoxy was defended, amongst others, by Ames [1438; 1440], William Prynne [1223], Samuel Rutherford [1305], Matthew Slade (Sladus) [1262], William Twisse [246], and John Williams [1233]. The view of the Arminians, or Dutch Remonstrants, was expounded in at least two works in Webster's possession, John Pocklington's Altare christianum (a defence of altar rails) [1227], and an anonymous Apologia for the Remonstrants published in 1629 [1288].

The most significant aspect of this large collection of Calvinist writings is its emphasis upon works of Calvinist exegesis (thirty-four volumes, or 25 per cent of the total for Calvinist authors). Two commentators in particular seem to have excited Webster's interest: the Scottish cleric Robert Rollock (1555?-1599) (eight volumes) and the German Ramist Johann Piscator of Herborn (1546-1625) (six volumes). Both were widely cited in Webster's later published works, alongside another leading German Calvinist and prolific biblical commentator, Amandus Polanus of Basle (three volumes). Webster clearly approved of works of this kind, the Ramist nature of many (Polanus was also a Ramist) undoubtedly providing much of their appeal (cf. below p. 41). It is worth noting, however, that Webster's liking for learned scriptural analysis was not restricted to Calvinist exegetes. In all, he owned sixty-two volumes (or 15.6 per cent of the total number of theological works) of biblical commentary covering a wide spectrum of theological views from ancient patristic and scholastic sources to modern Catholic and Lutheran commentators. ${ }^{90}$

Leaving to one side the question of confessional allegiance and influence posed by these works, it is difficult to avoid the conclusion that writings of this kind possessed distinct appeal for Webster. Predictably perhaps, there is a discernible emphasis upon

\footnotetext{
${ }^{89}$ These were: Jean Daillé[1088], Pierre Du Moulin the Elder [684; 1.445], François Hotman[1441], Pierre de la Ramée (Ramus) [1334; 1402], Jean de L'Espine [1342], Philippe de Mornay [1326], André Rivet [1282], and Daniel Tilenus [1307; 1398]. Tilenus (1563-1633), Professor of Theology at Sedan and Saumur, was later to convert to Arminianism (see, e.g., item 1419).

${ }^{90}$ Particular mention should be made of the seven volumes of commentaries by the Zwinglian Rudolph Walther (Gualtherus) $(1518-86)[148 ; 1319 ; 1332 ; 1404 ; 1405 ; 1411 ; 1414]$. Lutheran exegetes are represented by David Chytraeus (1530-1600) [1417], Solomon Gesner (1559-1605) [1408], Polycarp Leyser (1552-1610) [1286], Joannes Tarnovius (1586-1629) [1272], and Otto Brunfels (c. 1488-1534) [64].
} 


\section{The library of John Webster}

commentaries on the New Testament (thirty-five volumes in all), a reflection in all probability of Webster's antinomianism (cf. above p. 3). This thirst for biblical scholarship was complemented in Webster's case by the possession of countless Bibles, concordances, and scriptural lexicons in a variety of languages (English, Latin, Greek, Hebrew, French, Italian, German, and Dutch) ${ }^{91}$ The view that thus begins to emerge from this litany of learned sources and aids to biblical study is one of a highly educated man, immersed in the knowledge of the scriptures and fully conversant with orthodox Protestant, especially Calvinist, interpretations of the word of God. It would appear to follow, therefore, that when Webster opted to reject the orthodox Calvinism of the English church, he did so in complete understanding of the scriptural and theological foundations upon which the reformed faith in England was based. This much is evident from a cursory reading of the contents of Webster's library. What is more difficult to ascertain is the extent to which Webster's semi-mystical faith of the spirit was itself derived from conventional and orthodox sources (see below pp. 33-34).

A further clue to Webster's theological development may be found in the frequency with which certain books of the Bible recur as the object of learned discussion and commentary. Genesis, Psalms, and Revelation appear most often (five volumes apiece), with commentaries on the books of Daniel and Romans almost as popular (four volumes each). Paul's epistle to the Romans, of course, possessed a political as well as a religious significance, with the Pauline injunction to "honour the powers that be" (Romans, 13), the subject of much debate in Protestant circles throughout this period. ${ }^{92}$ Genesis and Psalms, on the other hand, were naturally well-favoured by all literate Christians, both for study and religious edification. In the context of Webster's proven attraction to millenial ideas in the 1650s (above pp. 2-3), undoubtedly the most intriguing entries in the catalogue are the nine commentaries upon the two prophetic books, Daniel and Revelation. All were written by Protestant scholars, three explicitly associating papal rule at Rome with the biblical figure of Antichrist. ${ }^{93}$ This was a popular theme of many other works in Webster's possession-the connexion between Pope and Antichrist was repeated, for example, by David Pareus [1435], Gabriel Powel [1331], Lambert Daneau [1350], and Andrew Willet [143] -and it fits into another recurring theme of the library, its pronounced anti-Catholic bent. ${ }^{94}$

\footnotetext{
${ }^{91}$ Webster owned fourteen Bibles (six Latin, two English, two Hebrew, and one French, Dutch, Italian and unspecified) and twelve testaments, psalters, etc. In addition, he possessed four concordances and four biblical lexicons, as well as a number of treatises designed specifically to assist with the study of the scriptures. Most were guides to the Hebrew tongue; cf. below pp. 38-39. The various Bibles and commentaries in Webster's possession were extensively cited in his later works.

92 All four commentaries on Romans were written by Protestant scholars. The most important, in terms of its political implications, was undoubtedly that by the Silesian humanist and Calvinist Professor of Theology at Heidelberg, David Pareus (1548-1622). In his Latin commentary on Romans [243], Pareus taught the doctrine of lawful resistance against those secular authorities who failed in their religious duties to their subjects. In England, James I ordered the work to be burned. The Scottish Calvinist, John Knox (1505-72) had adumbrated a similar view, of course, in his Appellation [1384].

${ }_{93}$ These were Thomas Brightman's two commentaries on Revelation and Daniel [1293; 1468] and John Bale's The image of bothe churches [1356], the latter a scathing and frequently scurrilous denunciation of the Roman church, written in the form of a commentary upon the book of Revelation.

94 Websterowned at least twenty-two volumesconcerned solely with polemicalordoctrinalattacksupon the Catholic church. A number of these were aimed at the Jesuits in general, and the views of Robert Bellarmine in particular.
} 


\section{The library of John Webster}

Strangely enough, however, there is a general paucity of works of any kind that deal with millenial themes in the period of most acute crisis in Webster's life-time, the 1640 s and 1650 s. Only a single work, a commentary on Revelation by the puritan divine, Francis Woodcock [1216], is to be found in this category. Published in 1643, it was an attempt to explain the current turmoil in England by placing the events of the time within the framework of the eleventh chapter of Revelation. Of far greater interest (though not strictly speaking a work concerned with the biblical millennium) was Paul Felgenhauer's Postilion (London, 1655) [375]. Ostensibly a work of astrological prophecy, the existence of this radical tract on the shelves of Webster's library points to a continuing interest on Webster's part in the theme of millenial reform in interregnum England. Its message of impending, fundamental change in all areas of human activity, coupled with Felgenhauer's prediction that the earth and the heavens would be made anew, was wholly in keeping with Webster's earlier pronouncements in $1653 .{ }^{95}$

In particular, Felgenhauer's sweeping indictment of conventional wisdom and scholastic education must have elicited a sympathetic response from the disillusioned radical who, only a few years earlier, had voiced much the same opinions with respect to the English universities. Felgenhauer, for example, chastised the Aristotelians, who "thinke not that any Physicks can be learned in the Bible", and he went on to admonish such men for holding the view that "that which is true in Theology does not hold in Phylosophy". According to Felgenhauer, these men were responsible for the destruction of that essential unity that once reigned between man, nature, and God, a common theme of radical literature in the $1650 \mathrm{~s}$. And Webster would surely have agreed with Felgenhauer's concluding remark that: "yee Book-men . . . have filled the world full of Bookes, which are endlesse and numberlesse, nothing else but that you thereby are more and more scattered, confused and intricated". 96

Felgenhauer's comprehensive assault upon established learning, religious hypocrisy, and traditional forms of government was just one of a number of radical tracts in Webster's library which together point to the most obvious source for Webster's own disaffection in the 1650s. In all, works of this nature total thirty-three volumes (8.3 per cent of the theological works) and cover a broad spectrum of unorthodox religious ideas and beliefs. Many obviously have a bearing on the development of Webster's own ideas. Others may help to shed light upon his subsequent disillusionment with the radical cause. It would, of course, be wrong to place too much emphasis on single works, but the fact that Webster possessed so few dating from this period, and that the majority were distinctly radical in tone, would seem to vindicate careful scrutiny of these particular volumes: ${ }^{97}$

\footnotetext{
${ }^{95}$ Felgenhauer(1593-1677)was a Bohemianexilewhostudied theologyat Wittenberg, but thereafter(about 1620) became a self-styled prophet for Rosicrucian-Behmenist reform.

96 Paul Felgenhauer, Postilion, or a new almanacke, London, H. Crips \& L. Lloyd, 1655, pp. 23, 30, 36-37, 37-38. Felgenhauer also predicted a thorough reformation of the medical profession, including the discovery of a universal medicine which would cure all diseases; ibid., p. 42.

97 It is possible that Webster'scollection of radical literature was much larger in the $1650 \mathrm{~s}$. In The displaying, pp. 293-294, 300, Webster referred to the loss of a number of his papers and books some time in 1658 . These were clearly confiscated as the result of a judicial inquiry or investigation into Webster's affairs at this time. Two explanations come to mind. First, on 2 November 1657, Webster appealed to an old friend and acquaintance, John Lambert, requesting assistance in a suit brought against him by one Robert Inman. Inman was claiming compensation for the loss of an animal requisitioned by Webster in 1648 during the
} 
The single most important source for Webster's religious heterodoxy in the 1650 s probably derived from his profound admiration for the writings of the Silesian mystic Jacob Boehme (1575-1624). Cited with approval on numerous occasions (see above p. 3), Webster owned eleven volumes of Boehme's writings, including a folio edition in English of the Mysterium magnum [69], a detailed commentary on Genesis. Moreover, if my identification of item 467 is correct (" 8 volumes of ye writeings of Jacob Behmen"), then Webster's public recantation from the radical cause in about 1657-58 did not appear to dampen his enthusiasm for Behmenist literature. Whatever the case, Boehme's simple message that all men were united in the brotherhood of the holy spirit, and his belief in the superfluous nature of doctrinal and liturgical controversy, were echoed throughout Webster's early theological works. It is not surprising, therefore, that one of Webster's few known associates during the 1650s was the Welsh radical, William Erbery (1604-54), who was himself deeply imbued with Behmenist beliefs, and whose posthumous writings [452], edited by Webster in 1658, are to be found in the catalogue. ${ }^{98}$ It is not inconceivable that Webster may also have shared the company of another Behmenist (and ranter sympathizer) John Pordage (1607-81), who knew Erbery and whose apologetic narration Innocence appearing (London, 1655) [168] was also to be found on Webster's shelves. ${ }^{99}$

Another source for Webster's aversion to doctrinal orthodoxy and religious uniformity was the German mystic Valentine Weigel (1533-88). Webster owned two curious, but very influential, tracts by Weigel [373; 1370], both of which were translated into English in the late 1640s. In Of the life of Christ [1370], Weigel had stressed the idea that salvation was not tied to the observation of the sacraments or other human inventions in religion, but was rather the gift of pure faith. All men, Weigel claimed, possessed access to the transforming power of faith, which was acquired through belief in the inner spiritual Christ. Most men chose to reject this free gift and opted instead to follow the path of base "Adamic man". Those, however, who opened their hearts to the principle of the "Christ Life" within them were automatically received into membership of the true church, an invisible congregation of believers united by their common faith in the inner Christ. The result was a religion devoid of doctrine and ceremonies, tolerant and unworldly, which, like that professed by Webster in the 1650 s, appealed to all men. Of faith, Weigel wrote, it "comes by inward hearing". He went on:

\footnotetext{
second civil war. There may well have been a religious motive in the action brought by Inman against Webster, since there was a local Presbyterian clergyman of that name. Second, Webster had at about this time bought more sequestered land that was the subject of a long and acrimonious dispute in Clitheroe. The action against Webster may well have been related to this incident. See CSPD, 1657-58, p. 302; Marchant, op. cit., note 2 above, p. 256; Weeks, op. cit., note 4 above, pp. 68-70 and passim.

98 The appearance of Erbery's works [452] in close proximity to Webster's own radical writings [443; 445; $449 ; 451]$ almost certainly confirms Webster as the identity of the editor, J.W. It is just possible that Webster may also have been the author of items 442 and 447 ("The care of ye good Samaritan etc"), which I have been unable to locate and which may no longer be extant.

99 Pordage's Innocence appearing, London, Giles Calvert, 1655, is a long and detailed account of Pordage's troubled period as rector of Bradfield in Berkshire in the early 1650s. Could Webster have known Pordage? The rectory at Bradfield was, of course, a popular refuge for a variety of radical spokesmen in the 1640 s and 1650 s. Like Webster, Pordage had served as a physician to Parliament in the 1640 s, and he also shared Webster's interest in astrology. See Hill, op. cit., note 3 above, pp. 180-181; CSPD, 1655, p. 160.
} 
Good books, outward verbal ministry have their place, they testify to the real Treasure, they are witnesses to the inner Word within us, but Faith is not tied to books, it is a new nativity which cannot be found in a book. He who hath the inward Schoolmaster loseth nothing of his Salvation although all preachers should be dead and all books burned. ${ }^{100}$

One of the chief features of both Boehme's and Weigel's mystical reasoning was its tendency to interpret the message of the scriptures by depicting the biblical struggle between good and evil as one large allegory for the battle that took place within the hearts and souls of each and every believer. These ideas gained wide currency in England during the 1640s, and it is likely that Webster encountered them at this time and then adapted them to his own religious ends. Webster's insistence, for example, that Satan and Antichrist existed in man only as metaphors for sin and evil (cf. above pp. 2-3) may well have derived from Joseph Salmon's Antichrist in man (London, 1647) [1367a]. Similar ideas are to be found in the works of William Erbery and the American Familist, Samuel Gorton (d.1677). In the latter's Incorruptible key (London, 1647) [464], the author interpreted the biblical references to witchcraft to mean "those spiritual juglings" that the learned ministers employed "by art, and humane learning . . . in and about the word of God". ${ }^{101}$ Webster's interest in Gorton's work was maintained until the late 1650s, since he also possessed his Antidote against the common plague (London, 1657) [458]. In this work (addressed to Oliver Cromwell), Gorton defended the notion that Antichrist was "not to be confined to any one particular man, or devil", and he repeated his earlier suggestion that the clergy were little better than the witches they persecuted. ${ }^{102}$ Published in 1657 , this was one of the latest radical tracts in Webster's possession, and alongside works by Erbery, Salmon, John Biddle [1189a], William Dell [450], Robert Everard [1364], and an anonymous group of Quakers [455], it provides a limited but nonetheless fascinating glimpse into the reading habits of one such radical. ${ }^{103}$

In the same year as Gorton's Antidote, the Independent minister, John Owen (1616-83), published a defence of congregationalism under the title Of schisme (London, 1657) [1373]. It is one of the very few works in Webster's ownership dating from this period that represents a more moderate approach to church affairs, and as

\footnotetext{
100 Quoted in Rufus M. Jones, Spiritual reformers in the sixteenth and seventeenth centuries, London, Macmillan, 1914, pp. 146-147. Cf. Webster's view that "reason is a monster . . but faith is that pure and divine gift and the work of God that leads the heart of man in the light and power of the Spirit of Christ"; John Webster, op. cit., note 4 above, p. 17.

${ }_{101}$ For Salmon, see Hill, op. cit., note 3 above,. pp. 174 176; Samuel Gorton, An incorruptible key, London, 1647 , p. 22. Gorton, born in Lancashire, emigrated to America in 1636 where, with a faithful band of followers, he was constantly in trouble with the colonial authorities for flouting the laws and religious conventions of the time. In 1644, he returned to England in order to pursue a claim to land in Rhode Island, but was back in America by 1648 where he remained until his death in 1677. See DNB, vol. 12, pp. $251-253$.

102 Gorton, An antidote against the common plague of the world, London, A.Crook, 1657,pp.60,151-152; cf. Webster, above p. 3 n7.

${ }^{103}$ Webster later reproached the Quakers for their excessive trust in "the guidance of the Spirit", despite the fact (or because of it?) that he was himself approached by a member of that sect, Thomas Lawson, with a view to recruitment. See Webster, op. cit., note 15 above, p. 138; Friends Library, Swarthmore MSS, vol. 7, f23b. Unfortunately, the letter from Lawson to Webster is undated. Interestingly, Lawson wrote a tract in 1679 which is reminiscent in many respects of Webster's Academiarum examen. In Dagon's fall before the ark, London?, 1679, Lawson attacked the "ethnick" philosophy of Aristotle and Galen ("profess'd enemy to Christ") and advanced the cause of utilitarian university education based upon authors such as Oswald Croll and van Helmont; ibid, pp. 2-3, 44, 45-46, 52-54, 87-88.
} 
such may well indicate a further sign of Webster's growing disillusionment with the cause of radicalism. In this work, Owen professed to hold a strong desire for religious unity and peace but concluded, in much the same way as Webster in 1658 (above pp. 6-7), that the time was not yet right. Owen therefore cautioned that it was the duty of all men to yield to the present system of church government in England, a policy born out of practical necessity and one that would sorely test the consciences of many puritan ministers in 1660 . Webster, as we have seen (above pp. 6-7), was probably reconciled to this way of thinking by the late 1650 s, and so had little difficulty in accepting the restored church in 1660 (note his possession of a copy of the special prayer devised to be read on the anniversary on the death of Charles I, and published in 1661 [920]).

On a superficial level at least, there seems little reason to doubt the fact of Webster's public acknowledgement of the restoration church. It is just possible, however, that Webster combined outward conformity to the church of England after 1660 with a continuing private appreciation of the merits of radical religious beliefs. This insinuation was suggested in the case of certain elements of Webster's reasoning with regard to witchcraft (above pp. 11-12). It may also be inferred from the admittedly ambiguous evidence to be found in that section of Webster's library entitled "Bookes lent \& omitted in ye form ${ }^{r}$ Catologue" (Section M). Since the catalogue was probably compiled shortly before Webster's death in 1682 , it is evident from the references to his own published sermons [1176], two volumes of Socinian writings [1189a-b], and the "Works" of the Familist Hendrik Niclas [1197] that radical literature was still circulating in the Clitheroe region some twenty years after the restoration. It is not beyond the bounds of possibility, therefore, that Webster continued privately to disseminate the radical message whilst at the same time maintaining a public image of conformity. After all, such expediency was a key element in the survival of Familist groups like the Grindletonians. ${ }^{104}$

In the last resort, the whole issue of influence, and the extent to which it can be inferred from documents such as library catalogues, is one which defies precise analysis and evaluation. In Webster's case, I have merely attempted to suggest certain lines of speculation linking his known religious views with the volumes in his library. Naturally therefore, the emphasis of my comments has focused upon those works that espoused radical theological beliefs. One should not infer from this, however, that the other works of theology in his library were entirely unrelated to the formulation of Webster's own religious outlook. It is highly probable, for example, that the large number of orthodox Calvinist and Lutheran authorities in Webster's library may have provided him with an alternative (or original) source for the view that human reason and learning were immaterial to the acquisition of grace. Uncertainty in learned Protestant circles as to the exact function and place of reason was a common theme of much Calvinist and Lutheran literature. ${ }^{105}$ Inevitably, the doubt that this created in some minds as to the relevance of learned human authority in spiritual matters was a

\footnotetext{
104 One further piece of circumstantial evidence might be added. In Webster's will dated 3 January 1680, he bequeathed 40 s. "to the poore of the townshipp of Grindleton in Yorkshire". This bequest would seem to indicate that Webster had maintained his links with this old centre of heresy. See Appendix 1.

${ }^{105}$ For a recent survey of the subject, see Morgan, op. cit., note 10 above, pp. 41-78.
} 
double-edged sword and produced a popular obscurantism that was never the object of the original authors. An example of this kind of work was Jean Daille's Traicté de l'employ des sainct peres [1088] in which Daillé censured excessive reliance upon patristic and scholastic sources. Yet Webster reminds us that even sources such as these, frequently the object of Protestant scorn, were not entirely without merit. In Academiarum examen, for example, he repeatedly cited Saint John Chrysostom [136] as one source for the view that human learning was antithetical to true religion. One is reminded yet again of the fact that Webster was at heart a committed eclectic- a statement which applies as much to his theology as to his views on natural science. ${ }^{106}$

One should not exaggerate, however, the reaction against learned values and human reason in Protestant discourse which was generally outweighed by works in favour of such aids to salvation. Webster himself owned a number of the latter, including an exhaustive defence of learning and reason by the Englishman, Egeon Askew [appended to 1234], and the German Calvinist, Nicolaus Vedelius [774]. In addition to these, Webster also possessed numerous manuals for preachers, which were designed to illustrate the various uses of learning, reason, and logic in the construction of sermons (e.g., works by Bartholomew Keckermann [1410] and Niels Hemmingsen [1469]). ${ }^{107}$ Despite protestations to the contrary, Webster almost certainly imbibed elements of much of this literature, and was indebted, to some extent, to scholastic methods of theological argument and discourse. Indeed, his inconsistency in this respect was used by his adversaries to expose the flaws in his radical arguments. George Wither pointed out in 1653 that much of Webster's phraseology in theological matters was clothed in the language and logic of those scholastic conventions that he purported to despise. ${ }^{108}$ In theology too, then, one is faced with the paradox of a would-be reformer whose commitment to change was shaped as much by traditional, orthodox sources as it was by new ideas and beliefs.

\section{HISTORY}

The most conspicuous feature of Webster's large collection of historical works (169 volumes or 10.4 per cent) is its astonishing range. Although works of ancient history predominate (sixty-four volumes), Webster owned an impressive set of annals and histories of medieval and Renaissance Europe, as well as a substantial number of works relating to the history of the church. Most of the works relating to ancient Greece (eleven volumes) and Rome (thirty-seven volumes) can probably be accounted

\footnotetext{
106 John Webster, op. cit., note 4 above, pp. 3, 5, 11, 16. Daillé (1594-1670) was a leading French Calvinist and student of the Scottish theologian, John Cameron (1579?-1625), whose Myrothecium [244] was also in Webster's possession. He was pastor of the Protestant churches at Saumur (1626) and Charenton (1626-70), and was a close acquaintance of many of the most learned men of his day, including Mersenne. See Brian G. Armstrong, Calvinism and the Amyraut heresy: Protestant scholasticism and humanism in seventeenth-century France, Madison, University of Wisconsin Press, 1969, pp. 12-13.

107 To this list, one might add a curious little discourse written by the physician Richard Bunworth entitled Man in paradise, London, James Cottrel, 1656 [667], which purported to "vindicate the souls Prerogative in discerning the truths of Christian Religion with the Eye of Reason", ibid., sig.A6r-v. Published in 1656, this work may represent more circumstantial evidence for Webster's repudiation of radicalism at about this time.

108 G[eorge] W[ither], The modern states-man, London, Henry Hills, 1653, pp. 113-115. Wither was attacking Webster for his use of syllogisms, queries, consectaries, and responsions in his first published work, The saints guide.
} 
for by the fact that texts such as these were frequently used for instruction in the grammar schools of early modern England. Works such as Suetonius' imperial biographies $[67 ; 257 ; 1053 ; 1138 ; 1475]$ and Caesar's Commentaries $[746 ; 747 ; 832$; 1163] were commonly appropriated for general instruction in grammar, style, etc., as well as serving as models for classical historical study. As a grammar school teacher, it is logical to assume that Webster employed them for similar purposes, alongside a whole series of equally popular texts: Appian [104; 1161], Arrianus [120], Curtius Rufus [772; 1175], Diodorus Siculus [113], Dion Cassius [755], Dionysius [1162], Florus [725; 1146], Herodian [982; 1144], Herodotus [762; 769; 949], Livy [117; 1033], Lucanus [978; 1026], Pausanias [766], Tacitus [94; 1087], Thucydides [765], Trogus Pompeius [1145], and Xenophon [95]. These were, in turn, supplemented by other works on more specific aspects of the ancient past, the products of celebrated Renaissance scholars such as Justus Lipsius [216; 1174], Paolo Manuzio [1150; 1480], and Onofrio Panvinio [75].

Webster's interest in history was not apparently restricted to works of ancient history that can only have possessed a limited appeal for the Clitheroe reformer. Possession of Bodin's Methodus [776] and Buchanan's Rerum scoticarum historia [743] indicate a wider appreciation on Webster's part of new schools of historical writing. Even greater significance may rest, however, in the large number of British histories (twenty-four volumes) in Webster's possession, a symptom no doubt of that growing sense of national pride and destiny which was shared in this period by literate Englishmen of all religious and political backgrounds. Along with the works of Camden [128; 893; 922; 1171], Cotton [971], Hakluyt [171], Holinshed [129], Speed [127], and Stow [125; 933], Webster owned a series of lesser works which together set out to emphasize the glorious antecedents of the English people, and in some cases that of their monarchy.

Two works in particular stand out for comment, not so much for any intrinsic merit that they might possess, but rather for the prominence which they gave to the ancient historical myth that the kings of England were directly descended, through Arthur, from the Trojan founder of Britain, Brutus. The first, Sir John Price's Historiae britannicae defensio [897] has been described as "the major scholarly affirmation of the pro-Brutus-Arthur faction". ${ }^{109}$ The other, Thomas Heywood's Life of Merlin [468], reiterates the same theme, and extends the myth to include Charles I and the Stuarts (a strange work, one might think, to find in the hands of a parliamentarian). Webster's interest in such matters, however, was probably unrelated to either historical or political concerns. A much more likely explanation lies in Webster's extraordinary fondness for tales of Arthurian-style romance, which quite often took as their starting-point the Brutus-Arthur legend (see below pp. 36-37).

Despite the concentration of interest in British history, there are surprisingly few works to be found relating to recent events in Webster's own life-time in England and Scotland. The civil war, for example, features only twice, both works having been written from the royalist perspective (Bate [1470] and Wishart [754]). Seemingly of

109 Peter French, John Dee: the world of an Elizabethan magus, London, Routledge \& Kegan Paul, 1972, p. 195. French discusses this and similar works at length in the context of John Dee's thought and library, ibid., pp. 188-199. 


\section{The library of John Webster}

greater interest to Webster were events in late-sixteenth- and early-seventeenth-century Europe. Besides a number of works dealing with the Thirty Years War (e.g., Gualdo Priorato [179], Lundorp [1148; 1484], and Pomo [261]), Webster owned eight volumes relating to the war between the Spanish and the Dutch in the Low Countries, most of them written from a Catholic perspective (e.g., the works of the Jesuits, Hermannus Hugo [132] and Famianus Strada [745]). The religious significance of the events portrayed in these works was clearly not lost on Webster, who also owned nineteen volumes concerned specifically with aspects of church history. Again, Catholic authors are not ignored, the most important almost certainly the massive Epitome by Henri de Sponde of Cardinal Caesar Baronius' Annales ecclesiastici [68]. This was itself intended as a counter-reformation reply to the Protestant Magdeburg centuries [96], edited by Matthias Flacius (1520-75) and composed "to vindicate the historical rightness of the Lutheran reform". Similar in intent, but focusing upon the events of the reformation, was the Commentaries of Joannes Philippson (Sleidanus), a hugely popular work in Protestant Europe [154]. ${ }^{110}$

It is impossible in such a brief synopsis as this to provide a complete picture of the range of Webster's collection of historical works, which covered numerous topics and issues, and which spanned all periods of known history. Europe was comprehensively covered, with a noticeable emphasis upon Italian, especially Venetian, history. ${ }^{111}$ In addition, Webster owned historical accounts of the Turkish $[111 ; 259 ; 768 ; 1164]$ and Chinese [1097; 1157] nations, as well as a history in Spanish of the conquest of the new world [107]. Much supplementary historical information relating to non-European subjects was also available to Webster in the form of early travel journals, which proved highly popular in this period as general works of scholarly reference (for statistical purposes I have included these under the category of Natural Philosophy). Webster himself was greatly indebted to one such work, by the Jesuit, Joseph de Acosta (1539-1600) [919], which he cited extensively in his Metallographia. Equally popular were those by William Lithgow [923], George Sandys [185b], and the imperial ambassador, Gislenius de Bousbecq [1061], which all provided a wealth of miscellaneous information upon the customs and history of the Turkish people.

\section{LITERATURE}

One of the most surprising discoveries in Webster's whole library is contained in the 148 volumes that comprise works of ancient and modern literature. Of this total, more than a quarter (forty-one volumes) were prose romances and fictions, in Spanish,

${ }^{110}$ Oliver K. Olson, 'Matthias Flacius Illyricus', in Jill Raitt (editor), Shapers of religious traditions in Germany, Switzerland and Poland, 1560-1600, New Haven, Conn., Yale University Press, 1981, p. 14. For Philippson, see A.G. Dickens, 'Johannes Sleidan and Reformation history', in R.B. Knox (editor), Reformation, conformity and dissent: essays in honour of Geoffrey Nuttall, London, Epworth Press, 1977, pp. 17-43.

11 Among those works on Italian history are Guicciardini'scelebrated History in Italian [249], two volumes by Carlo Sigonio [97; 98] and a history of Genoa by Uberto Foglietta [99]. The proud historical traditions of republican Venice were dealt with by Contarini [1094], Justinianus [114], and Paruta [126], the latter an English translation, published during the interregnum in 1658. Webster also owned two works by Paolo Sarpi including his famous Historie of the Councel of Trent [118]. For discussion of many of these works, see William J. Bouwsma, Venice and the defence of republican liberty, Berkeley, California University Press, 1968. 


\section{The library of John Webster}

French, Italian, and English, many of them not published or translated until the 1640s and $1650 \mathrm{~s}$. The major source for these chivalric romances was the Brutus-Arthur legend (see above p. 35), which underwent dramatic literary embellishment in the late-fifteenth and early-sixteenth centuries at the hands of unknown Spanish authors. The most famous product of this school of writing were the stories of Amadis de Gaule [105; 1095], which were to form the basis of a whole genre of later Spanish, French, and Italian adaptations [e.g., the Palmerin-Palmendos series: 912; 953; 957; 1092]. Typically, these stories were set in either England or distant and fabulous eastern kingdoms (e.g., The historie of Trebizond by Thomas Gainsford [934]), and they featured fantastic tales of knightly deeds and amorous adventures, interspersed with magical interludes and similar literary devices. Moreover, in the course of time, other ancient stories and legends were grafted on to the original leitmotif of the Brutus-Arthur-Amadís series, the Ethiopian history of Heliodorus [902; 948; 950: in French, Greek, and English respectively] proving very influential in this respect.

Works of this kind can be interpreted and understood at various levels of meaning. Many clearly read them for pure enjoyment and little else, since they were certainly amongst the most popular forms of literature in sixteenth- and early-seventeenthcentury Europe. ${ }^{112}$ A more sophisticated audience, however, was meant to perceive a didactic purpose in these stories, ranging from princely advice and chivalric instruction to the conveyance of specific moral points. Such was the purpose of John Lyly's Euphues [914] and Sidney's Arcadia [180], the latter displaying another common feature of this genre, namely its idealization of rusticity (cf., for example, the Diana of Jorge de Montemayor [1096]). Of course, it is impossible to say what aspects of these novels attracted Webster's attention. But the mere fact that Webster, given his religious background, collected such works is itself quite extraordinary. Books of this kind, so one is generally led to believe, were anathema to most puritans and sectaries, who felt that they tended to corrupt the minds of their readers and distract them from their godly duties. Webster, however, far from rejecting literature of this kind, was actively engaged in the collection of the latest romances and fictions in the 1640s and 1650s-in the period, that is, of his own greatest commitment to the reform of learning and religion. ${ }^{113}$

Webster, in fact, had little to say about popular literature, ancient or modern, in Academiarum examen, apart from the vaguest indictment of excessive reliance upon pagan authors, poets, and dramatists. Poetry, rhetoric, and other branches of classical literature were not condemned outright by Webster, who, unlike many of his radical colleagues, was content to allow moderate use of such studies. One of the principal benefits of this learning was its contribution to the perfection of style and eloquence which Webster almost certainly employed in his capacity as grammar school master. In

112 The popularity of such works is discussed in Margaret Spufford, Small books and pleasant histories: popular fiction and its readership in seventeenth-century England, London, Methuen, 1981, pp. 219-237. For the importance of the Amadis stories, see John J. O'Connor, Amadis de Gaule and its influence on Elizabethan literature, New Brunswick, NJ, Rutgers University Press, 1970.

113 Works of this kind dating from the 1640 s and 1650 s include a five-volume edition of Gautier de Costes de la Calprenède's Cassandre [904], an English translation of Marin Le Roy's Polexander in folio [187], and two Spanish romances, again in English, by Francisco de Quintana [968] and Gonzalo de Céspedes Y Meneses [969]. To these, one might also add Sir William Davenant's poetic romance, Gondibert, first published in 1651 [926]. 
all, he owned forty-eight volumes of Roman and Greek poetry, prose, and drama, with works by Cicero and Virgil (six volumes apiece) predominant. Other authors, equally popular in the grammar school curriculum, included: Ovid [56;1040;1041; 1043; 1191], Aulus Gellius [909; 1155; 1474] Horace [1004; 1039], Lucian [227; 1038], Sallust [723; 1991], Aesop [985; 1074], Ausonius [1077], Hesiod [1034], Juvenal [1065], Martial [1110], Petronius [1057], and Pindar [240].

Drama, always a more equivocal subject for Protestant pedagogues, is less apparent in Webster's library. He owned only three volumes of classical drama (Euripides [1049], Plautus [1015], and Terence, in English translation [1186]) with two copies of the popular school text Terentius christianus by Cornelius Schonaeus [1024; 1058], an attempt to "clothe in the phrase and eloquence of Terence the old Bible stories". 114 Similarly, in rhetoric, Webster owned only a handful of classical texts (Quintilian [63; 1013], Cicero [1015], Demosthenes [1007], and Isocrates [998]), but these were bolstered in part by a number of more recent compilations by Renaissance rhetoricians. ${ }^{115}$ Interest in modern authorities, however, was most apparent in the field of poetry or poesy. Webster owned thirty-eight volumes of modern poetry and letters, including works by scholars of international repute such as the humanists Roger Ascham [1021], George Buchanan [1018], Guillaume Budé [62], and Joseph Scaliger [1016]. He also seems to have admired a number of British poets, since he collected the anthologies of Thomas Carew [979], William Davenant [926], Sir John Davies [981], Michael Drayton [174; 967], George Herbert [976], and Arthur Johnston [1059], as well as various miscellanies [955; 977]. Clearly, Webster's taste for literature was extensive and wide-ranging and hardly fits the stereotypical image of the puritan zealot and radical reformer. ${ }^{116}$

\section{LINGUISTICS}

From the evidence of Table 2 (above p. 19) and the ninety volumes that comprise Webster's collection of assorted dictionaries, manuals, and linguistic aids, it would seem that Webster was an able and proficient linguist. In addition to Latin, Greek, and Hebrew, he would appear to have mastered French, Italian, Spanish, and German, but not Arabic. ${ }^{17}$ The great majority of works in this section fall into one of two categories: dictionaries and lexicons (twenty-five volumes), ${ }^{118}$ and manuals, grammars, and other aids to language learning (fifty-five volumes). ${ }^{119}$ Taken as a

\footnotetext{
114 Foster Watson, The English grammar schools to 1660: their curriculum and practice, Cambridge University Press, 1908, p. 322.

115 Clarke [866], Conti [1000], Heinsius [1003], Junius [800], Macropedius [1044], Ravisius Textor [1048], Talaeus (Talon) [1072], Vernulaeus [1107], and Wilke [1017].

${ }^{116} \mathrm{~A}$ further indication of the breadth of Webster's literary interests is provided by his possession of the works of Ben Jonson [170], an anonymous book of plays [916], an Italian copy of Ariosto's Orlando furioso [65], the works of Chaucer [115] and Thomas More [1172], a Spanish edition of Cervantes' Don Quixote [1098], the works of Rabelais [972], and a collection of satirical essays by George Wither [980].

117 Webster refers to his ignorance of Arabic in op. cit., note 21 above, p. 111 . He nonetheless owned one Arabic grammar by the celebrated linguist and orientalist, Thomas Erpenius (1584-1624) [853].

118 These may be broken down as follows: multi-lingual 7, Hebrew 3, English-Latin 2, Latin-Italian 2, Latin 1, Greek 1, Italian-English 1, Latin-German 1, Latin-Greek 1, Latin-Teuton 1, Spanish-English 1, Spanish-French 1, Syriac 1, miscellaneous subject dictionaries 2 .

119 These may be broken down as follows: Hebrew 11, Latin 11, French 8, Greek 6, Italian 5, Greek-Latin 3, Spanish 3, English 2, Arabic 1, Chaldeo-Syriac 1, German 1, Latin-French 1, multi-lingual 2.
} 
whole, the preponderance of Hebrew (fourteen volumes), Latin (twelve volumes), and Greek (seven volumes) is entirely predictable. Not only was knowledge of all three languages considered an essential accoutrement for serious biblical scholarship, but skill in these languages was also established as a staple element in the curriculum of the grammar schools. Webster must therefore have used many of these works in his teaching duties and almost certainly applied them to his interest in scriptural exegesis (cf. above pp. 28-29). ${ }^{120}$

On the whole, there is little that is remarkable or noteworthy about these works. The numerous Latin grammars and manuals are primarily humanistic in tone and include a number of popular educational manuals designed to assist Latin instruction for the young [e.g., Vives' Colloquia: 1009]. The works of Erasmus in this field were particularly favoured $[881 ; 1027 ; 1028 ; 1029 ; 1035 ; 1036]$. A hint of greater innovation is to be found in the works of Joseph Webbe [1025; 1105] and John Brinsley [1501], both of whom were applauded by Webster for their novel approaches to the teaching of Latin grammar. ${ }^{121}$ Both men disapproved of the traditional pedantry of language instruction in the grammar schools, and Webster was particularly enamoured with the thought of Brinsley in this respect, who, he claimed, had done away with rules and method in grammar teaching. ${ }^{122}$ This movement away from more formal methods of language instruction was epitomized by the radically new approach of Jan Amos Komenský (Comenius) [862; 870], who, in Webster's words, had attempted "to lay down a platform ... that youth might as well in their tender years receive the impression of the knowing of matter, and things, as of words, and that with as much ease, brevity and facility". 123

The appeal of Comenius's linguistic theories lay in the practical benefits to learning in general which such methods were purported to produce. Science, in particular, stood to gain from the implementation of the Comenian system, which attempted to substitute an emphasis on words for an emphasis on things. In England, ideas of this kind were extremely influential among the Baconian reformers, who, in some cases, extended the scope of their linguistic research to the quest for a universal language. Webster had, of course, shown a great deal of interest in such schemes in Academiarum examen, citing Jacob Boehme as the source of his belief that one day the universal language of nature would be rediscovered (above p. 3). According to Webster, all learning, not just science, stood to benefit from this discovery, a view which no doubt accounts for his possession of other works concerned with this subject (John Wilkins [588], Francis Lodowick [377], and Cave Beck [964]). Beck's Universal character (1657)

120 Of Greek and Hebrew, Webster wrote "we have in our younger years both studied and taught them to others," op. cit., note 15 above, p. 106. Two of the most popular manuals for the instruction of Hebrew in schools were Buxtorf's Epitome [868; 879] and Martinius' grammar [844; 867; 876; 878]. See W.A.L. Vincent, The grammar schools: their continuing tradition, $1660-1714$, London, John Murray, 1969, p. 80.

121 John Webster, op. cit., note 4 above, pp. 23-24.

122 For Brinsley, see esp. Rosemary O'Day, Education and society, 1500-1800, London, Longman, 1982, pp. 47-53; Morgan, op. cit., note 10 above, pp. 195-199 and passim. In praising Brinsley for his opposition to rules in grammar, Webster was accused by the Presbyterian Thomas Hall of inaccuracy and inconsistency since Brinsley's method, according to Hall, was well known "to hath reference to Rules". Thomas Hall, Vindiciae literarum, London, N. Webb \& W. Grantham, 1654, p. 201.

${ }^{123}$ John Webster, op. cit., note 4 above, p. 22. See also item 1500, an English adaptation of Comenius' Janua linguarum. 
is an especially interesting item. Not only does it hint at Webster's continuing fascination with this particular subject in the late 1650s, but Beck's use of mathematics to solve this difficult problem reflects Webster's own faith in this particular field of learning (cf. above p. 24). ${ }^{124}$

\section{PHILOSOPHY (ETHICS, LOGIC, AND METAPHYSICS)}

One of the smallest categories of works in Webster's library consists of the three branches of philosophy: ethics, logic, and metaphysics (fifty-six volumes). All three, to some extent, were considered in need of reform by Webster in the 1650s, with metaphysics singled out for special criticism. Metaphysics was, in fact, one of the few subjects under-represented in Webster's library (nine volumes), and most of these were wholly traditional in their adherence to Aristotelian method and form. ${ }^{125}$ Webster seems to have attached far greater significance to the study of logic (twenty-two volumes) and ethics (twenty volumes), subjects which he considered worthy of university study once they too had been purified from the corruptions of Aristotle and the schoolmen. In both cases, however, Webster possessed a solid grounding in the works of traditional authors, which formed the basis of instruction at Oxford and Cambridge.

In ethics (twenty volumes), Webster owned a substantial body of classical texts and learned commentaries on Aristotle's Ethica Nicomachea [798], including those of Freigius [805], Golius [804], Lefèvre d'Étaples [1268], Magirus [822], Pavone [812], Riger [1121], and Scribonius [1115]. ${ }^{126}$ One of Webster's major criticisms of works such as these was that they based instruction in morality on pagan authors. He did, however, offer alternative sources of ancient wisdom for ethical study in the shape of Seneca [80] and Epictetus [724]. ${ }^{127} \mathrm{He}$ also approved of the Calvinist Lambert Daneau's Ethices christianae [783], which, as its title suggests, was an attempt to create a system of ethical enquiry based entirely upon non-pagan sources, and he warmly applauded the ethical endeavours of Descartes and Philip Melanchthon. ${ }^{128}$ One further source of moral instruction, unmentioned by Webster in Academiarum examen, was the emblem book. Webster owned five specimens of this popular, multi-purpose

\footnotetext{
124 John Webster, op. cit., note 4 above, pp. 25-32. A similar concern for the universal language, and its application to occult learning, is discernible in those works of cryptography owned by Webster. These included three volumes by Johann Tritheim (1462-1516) [471;472; 586], as well as a large folio on the subject by Gustavus Selenus (b.1579) [38]. For the latter, see especially Wayne Shumaker, Renaissance curiosa, Burlington, Centre for Medieval and Renaissance Studies, 1982, pp. 99-105.

125 John Webster, op. cit., note 4 above, pp. 84-86, 107. Webster owned works on metaphysics by a number of distinguished Protestant scholars, among them Robert Baron [1118], Gilbert Jacchaeus [1120b], Bartholomew Keckermann [808], Jacob Martini [809; 827], and Christoph Scheibler [251]. In order to remedy the deficiencies of traditional studies such as these, Webster advised the study of the metaphysical works of Descartes.

126 In addition to these works, Webster had access to further classical expositions of A ristotelian ethics in the general manuals of authors such as Eustachius [793] and Jean de Champaignac [790]. The former was commonly used as a standard text at Cambridge during the seventeenth century. See for example, Curtis, op. cit., note 56 above, pp. 110-112; Kearney, op. cit., note 60 above, p. 105.

${ }^{127}$ Of Epictetus' Enchiridion [724], a small duodecimo, Webster wrote that it contained "more pretious treasure than all the great volumes of Aristotle", op. cit., note 4 above, p. 88. Webster might also have recommended the writings of Plutarch $[44,773]$ and Cebes [896; 256].

128 Ibid., pp. 86-88, 107-108.
} 
form of literature (Alciatus [780; 1139], Boissard [429], Junius [1143], and Schoonhovius [413]), which, in its combination of poetry, art, and philosophy, possessed obvious pedagogical uses.

In the case of logic, there already existed in Webster's time a framework for wholesale reform of the Aristotelian system of logic in the shape of Ramism. Not surprisingly, Webster owned a number of Ramist texts. In addition to two copies of the Dialectica of La Ramée (Ramus) [801; 802], Webster possessed the Ramist manuals of Alsted [792; 826], Downame [811], Freigius [805], Granger [474], and Hotman [1129]. He was also well versed in the works of a number of Protestant theologians who applied Ramist logic to their religious studies (e.g., in England, Downame, Ames, Perkins, and Fenner; in Europe, Alsted, Piscator, and Polanus). The chief end of Ramism was to simplify the actual process of learning and to make knowledge more accessible and factual, rather than conjectural. One of the main criticisms levelled against scholastic logic (by Webster amongst others) was that it was incapable of producing new knowledge or understanding. Ramism clearly could, and one area to which it was commonly applied was the puritan sermon. Granger's Syntagma logicam (London, 1620) [474], for example, was a comprehensive guide to the new logic which dealt exhaustively with the various religious applications of Ramism. Interestingly, Webster had little to say about Ramus's methods in Academiarum examen. If this is indicative of an equivocal response on Webster's part to Ramism, then it may well have arisen because of its associations with orthodox Calvinism. ${ }^{129}$

In logic, as in so many other areas of learning, Webster was fully acquainted with traditional Aristotelian method. The logical works of Aristotle [234; 807] were supplemented by numerous manuals and expositions of peripatetic logic, many of which were commonly employed as standard texts in the schools and universities of seventeenth-century England (e.g., Burgersdijck [1124], Seton [1117], Stekius [777], Sturm [775], and Titelman [803]). Moreover, many of these works were prepared with the same object in mind as that of the Ramist Granger. John Case's Summa [473], for example, was designed specifically to accommodate Aristotelian logic to scriptural analysis (cf. Titelman [803]). A similar motive lay behind the numerous systematic treatises of the eclectic Danzig logician, Bartholomew Keckermann (1571-1609). Webster owned no less than five copies of Keckermann's Systema logica [787; 796; 797; $814 ; 1123$ ], a work widely used for pedagogical purposes in this period and one which Webster almost certainly employed in his own teaching. ${ }^{130}$

\section{LAW AND POLITICS}

The final section of Webster's library, and the smallest, comprises those works concerned with law and politics (fifty volumes). In both cases, Webster's literary interest in these subjects was confined to very few books, and in the case of law presents

\footnotetext{
${ }^{129}$ I have found only two references to Ramus in Webster's writings: see ibid., p. 91, and Webster, op. cit., note 15 above, p. 344. In all, Webster owned nine volumes by Ramus, as well as the Rhetorica of Talaeus (Talon) [1072], which has been partially attributed to Ramus.

${ }^{130}$ Altogether, Webster possessed twelve volumes of Keckermann's writings, including a one-volume edition of his Opera [235]. Keckermann's works were popular in England, and America, where they were frequently taught at Harvard. See Morgan, op. cit., note 10 above, p. 261; Curtis, op. cit., note 56 above, p. $284 \mathrm{n}$.
} 
little of interest. Most of the law books (twenty-four volumes) were the work of English jurists and legal commentators and cover a wide range of subjects from land law, conveyancing, court administration, and wills to general compilations of the laws and statutes of England, including Magna Carta [1454]. These works would have possessed a twofold interest for Webster. First, Webster was a property owner, and a litigious one at that, who had made a number of enemies through his property transactions in delinquent land during the $1650 \mathrm{~s}$. And second, as resident magistrate for Clitheroe on three separate occasions, he would certainly have required some background knowledge of the English common law. ${ }^{131}$ The remaining legal works, miscellaneous collections of practical and theoretical law, represent the work of a number of continental jurists, including such celebrated figures as François Hotman [1443; 1455], Julius Pacius [1453], and Ulrich Zasius [1478].

Webster's books on politics (twenty-six volumes) present more of a problem in that they fit no clear pattern and certainly disallow any attempt to pass judgement on Webster's own political beliefs. These were not directly alluded to by Webster in any of his published writings. It nonetheless seems logical to assume that for much of the 1640 s and 1650 s, Webster was actively engaged in support of Parliament in its struggle with Charles I, and thereafter backed the Cromwellian republic. In 1660, his allegiance to the monarchy was restored (above pp. 6-7), though whether through ideological commitment or political expediency is difficult to determine.

Considering Webster's support for Parliament in 1648 and his involvement in radical circles in London in 1653, one is surprised to find that Webster owned so few works of an overtly political nature. Those that he did own, moreover, display little sympathy for the parliamentarian cause and include a number of popular defences of the deposed Stuarts. Foremost among works of this kind were the anonymous Eikon basilicon [988], Saumaise's reply to Milton [1436], and George Bate's Elenchus motuum nuperorum [1470]. Equally unexpected is the presence of a number of European expositions of absolutist and divine right theories. These include the works of two French political commentators, Boitet de Frauville [1089] and Guez de Balzac [242], as well as William Barclay's De potestate papae [1346]. ${ }^{132}$

From the evidence of the library catalogue, Webster was not apparently attracted to the ideas of the constitutional theorists, English or European, and apart from a few volumes advocating the virtues of republicanism as an ideal political form, ${ }^{133}$ there is little here to indicate commitment to radical political change. Other political works include examples of the "mirror for princes" genre, which tended to reinforce political

${ }^{131}$ Weeks, op. cit., note 4 above, pp. 94-97.

132 William Barclay (1546-1608) was Professor of Civil Law at Pont-a-Mousson and Angers. His De potestate papae [1346] was composed primarily to rebut the view that the Papacy possessed the right to interfere in the secular affairs of princes. In the process, he set out a strong defence of divine right monarchy and the illegality of resistance to royal authority. See J. W. Allen, $A$ history of political thought in the sixteenth century, London, Methuen, 1928, pp. 390-393. Non-resistance was also taught by Lipsius in his Politicorum [1456].

${ }_{133}$ Republicanism was, of course, upheld in this way by Machiavelli [1399] and Francesco Patrizi, bishop of Gaeta (1412-94) [1132]. To these works one might add the propagandistic defences of Venetian republicanism found in the histories of Contarini [1094] and Paruta [126]; see also above p. 36n.111. The religious duty of subjects to resist tyrants was also propounded by Knox [1384] and Pareus [243]; see above p. 29n.92. It was also the object of practical demonstration in Buchanan's Scottish history [743]. 
absolutism (e.g., Guevara [992], Osorio da Fonseca [1483], and James I's Basilicon doron [758b]). A limited interest in the field of political study is also suggested by Webster's brief comments on the subject in Academiarum examen, in which he recommended the writings of Bodin [776], Hobbes [989], and Machiavelli [1399]. The works of Aristotle were presumably to be relegated to a minor position in the curriculum, but not abolished altogether, since they were felt to possess some valuable insights into this particular branch of learning. ${ }^{134}$

\section{CONCLUSIONS}

Hugh Trevor-Roper has described John Webster as "a learned and dogmatic auto-didact ... [ [and] a compulsive name dropper" who "uncritically sang the praises of all writers, who, from whatever position, had attacked ... Aristotle ... and Galen". ${ }^{135}$ In the light of the preceding analysis of Webster's library, I am inclined to the view that this represents a fair assessment of Webster the man, except perhaps in one respect. If Webster did name-drop in his writings, we now know that he did so from a position of complete familiarity with the sources that he cited. Likewise, his assault on the "ancients" in general, and Aristotle in particular, was not simply the typical knee-jerk response of all radicals in this period to the traditional university curriculum. It was rather the product of a man who in all probability had received a traditional university education and who opposed the wisdom of the "ancients" from a vantage-point of knowledge rather than ignorance (cf. William Dell whose works Webster owned [450]).

The extent of Webster's knowledge, and the range of his scholarly interests, was remarkable for a man so far removed for much of his life from the mainstream of intellectual activity in England. His library, dominated by works of medicine, natural philosophy, and divinity, must have been one of the largest private collections in the north of England. Unfortunately, however, it has not survived intact, nor as yet have any of the volumes that once formed part of the library come to light. Until that time, any attempt, my own included, to evaluate the meaning of these books for their original owner must remain speculative. I am nonetheless convinced that for those more expert than myself, the catalogue of Webster's library provides a unique insight into the mind of one of the leading proponents of radical educational, religious, and scientific change in seventeenth-century England.

\footnotetext{
134 Webster owned a single copy of Aristotle's Politica [794]. He also possessed an interesting commentary on Aristotle's political thought by the Englishman, John Case (d.1600). For Case's own eclecticism, based upon a firm grounding in the thought of Aristotle, see Charles B. Schmitt, 'John Case on art and nature', Ann. Sci., 1976, 33: 543-559.

${ }^{135}$ Hugh Trevor-Roper, 'The Paracelsian movement', in Renaissance essays, London, Secker \& Warburg, 1985 , p. 190.
} 